Proceeding Paper

\title{
Fluorescent Calix[4]arene-Oxacyclophane Sensor for Transition Metal Cations ${ }^{+}$
}

\author{
Alexandra I. Costa ${ }^{1,2}$, Patrícia D. Barata ${ }^{1,2}$ and José V. Prata ${ }^{1,2, *}$ \\ 1 Departamento de Engenharia Química, Instituto Superior de Engenharia de Lisboa, Instituto Politécnico de \\ Lisboa, R. Conselheiro Emídio Navarro, 1, 1959-007 Lisboa, Portugal; acosta@deq.isel.ipl.pt (A.I.C.); \\ pbarata@deq.isel.ipl.pt (P.D.B.) \\ 2 Centro de Química-Vila Real, Universidade de Trás-os-Montes e Alto Douro, 5001-801 Vila Real, Portugal \\ * Correspondence: jvprata@deq.isel.ipl.pt \\ + Presented at the 24th International Electronic Conference on Synthetic Organic Chemistry, \\ 15 November-15 December 2020; Available online: https://ecsoc-24.sciforum.net/.
}

Citation: Costa, A.I.; Barata, P.D.; Prata, J.V. Fluorescent Calix[4]areneOxacyclophane Sensor for Transition Metal Cations. Chem. Proc. 2021, 3, 40. https://doi.org/10.3390/ecsoc-2408453

Academic Editors: Julio A. Seijas and M. Pilar Vázquez-Tato

Published: 16 November 2020

Publisher's Note: MDPI stays neutral with regard to jurisdictional claims in published maps and institutional affiliations.

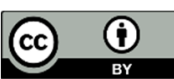

Copyright: (C) 2020 by the authors. Licensee MDPI, Basel, Switzerland. This article is an open access article distributed under the terms and conditions of the Creative Commons Attribution (CC BY) license (http://creativecommons.org/licenses /by/4.0/).

\begin{abstract}
The sensing behavior of a calix[4]arene-oxacyclophane-carbazole conjugate (1) towards $\mathrm{Cu}(\mathrm{I})$ ions was investigated. Contrary to the noteworthy sensitivity and selectivity previously found for $\mathrm{Cu}(\mathrm{II})$, the affinity of $\mathbf{1}$ for $\mathrm{Cu}(\mathrm{I})$ cations is much lower. Through fluorescence titration assays, the apparent binding constants $\left(K_{\mathrm{a}}\right)$ for the two ions were determined, showing that an affinity of over thirteen fold was displayed for $\mathrm{Cu}(\mathrm{II})$. Two $\mathrm{Cu}(\mathrm{I})$ counter-ions were used to determine possible effects on the binding event. It was found that acetate and iodide ions behave similarly, yielding $K_{a}$ of the same magnitude. Formation of a ground-state supramolecular complex between $\mathbf{1}$ and $\mathrm{Cu}(\mathrm{I})$ ions was not observed on UV-Vis titrations, in contrast to what was previously reported for $\mathrm{Cu}$ (II) using the same host. The affinity of $\mathbf{1}$ for Fe(III), a major biological competitor, was also assessed. The fluorescence of host $\mathbf{1}$ is quenched by Fe(III) ions although to a lesser extent (32\% less efficient than $\mathrm{Cu}(\mathrm{II})$ ). The study demonstrates that calixarene $\mathbf{1}$ is able to differentiate copper ions in two common oxidation states using fluorescence techniques, thereby suggesting its application for redox-active centers in biomimetic chemistry.
\end{abstract}

Keywords: calix[4]arene; copper(I); copper(II); iron(III); supramolecular; inclusion complex; fluorescence; sensor

\section{Introduction}

Development of sensitive and selective chemosensors for trace detection of transition metal cations (e.g., copper(II), copper(I) and iron(III) ions) abundant in nature, either associated with important biological processes or representing environmental hazards and health issues, is an attractive area of recent research [1-3]. Copper and iron cations are involved in crucial metabolic processes in the human body, such as cellular respiration, muscle contraction, enzyme synthesis and regulation of acid-base balance and osmotic pressure in cells [4,5].

Calix [4] arenes have been studied extensively as one of the most widespread scaffolds in host-guest chemistry because of their rigid structures (particularly important when the recognition and reporting events are to be undertaken in the fluid phase), making them perfect candidates for complexation studies with ions and neutral molecules [6,7]. Fluorescent calixarene-containing receptors have proven applications as sensors for a wide range of metal ions [7].

Calix[4]arene-oxacyclophane molecular receptors, either standing alone or integrated in a conjugated polymer chain, were recently described by us as excellent platforms for the recognition of $\mathrm{Cu}(\mathrm{II})$, with an outstanding selectivity by comparison with other tested metal ions, $(\mathrm{Hg}(\mathrm{II})$ and $\mathrm{Pb}(\mathrm{II})$ ) [8]. As a continuation of our previous 
studies, we were interested in determining the response of the same calixarene receptor 1 towards $\mathrm{Cu}(\mathrm{I})$, the ubiquitous counterpart of $\mathrm{Cu}(\mathrm{II})$ in biological redox activities. In addition, Fe(III), a d-block competitor ion in biological media, was also used in the study. This communication reports the preliminary results regarding the binding affinities of bicyclic calix[4]arene-carbazole probe 1 to $\mathrm{Cu}(\mathrm{I})$ and $\mathrm{Fe}(\mathrm{III})$ in organic media.

\section{Materials and Methods}

\subsection{Instruments and Methods}

Steady-state fluorescence spectra were acquired on a Perkin Elmer LS45 fluorimeter using a 1-cm quartz cuvette in right angle (RA) geometry at $25{ }^{\circ} \mathrm{C}$ in air-equilibrated conditions.

The titration studies were carried out at a constant concentration of the probe $\left(1.0 \times 10^{-7} \mathrm{M}\right)$ in a mixture of $\mathrm{CH}_{3} \mathrm{CN}: \mathrm{CHCl}_{3}(1: 1)$ using known amounts of metal cations in fluorophore solutions at $25^{\circ} \mathrm{C}$, being the spectra acquired after each addition. Copper acetate was previously solubilized in pyridine and added to the probe solution in $\mathrm{CH}_{3} \mathrm{CN}: \mathrm{CHCl}_{3}(1: 1)$.

\subsection{Materials}

Calix-OCP-2-CBZ (1) was synthesized according to our reported method [9] and fully characterized by FTIR, UV-Vis and NMR spectroscopies, showing high photostability and high quantum yield $\left(\Phi_{\mathrm{F}}=0.76\right.$ in $\left.\mathrm{CHCl}_{3}\right)$ [9].

$\mathrm{CuOAc}\left(97 \%\right.$, Aldrich), $\mathrm{Cu}(\mathrm{I})\left(98 \%\right.$, Aldrich), $\mathrm{Fe}\left(\mathrm{ClO}_{4}\right)_{3} . \mathrm{xH}_{2} \mathrm{O}$ (reagent grade, Alfa Aesar, Haverhill, MA, USA) and $\mathrm{Cu}\left(\mathrm{ClO}_{4}\right)_{2}(98 \%$, Acros Organics, Fair Lawn, NJ, USA) were used as received. Pyridine (99.5\%, Merck, Kenilworth, NJ, USA) was dried from $4 \AA$ molecular sieves. All other solvents were reagent grade and were purified and dried by standard methods.

\section{Results and Discussion}

\section{Sensing of Metal Cations}

Since a remarkable affinity of Calix-OCP-2-CBZ (compound 1; Chart 1) towards $\mathrm{Cu}$ (II) in organic media has been disclosed [8], further studies were foreseen to explore the behavior of such sensors to other biologically important transition metal ions, in particular copper (I) owing to its significance in biological systems where it appears in $\mathrm{Cu}(\mathrm{I}) / \mathrm{Cu}(\mathrm{II})$ redox pairs.

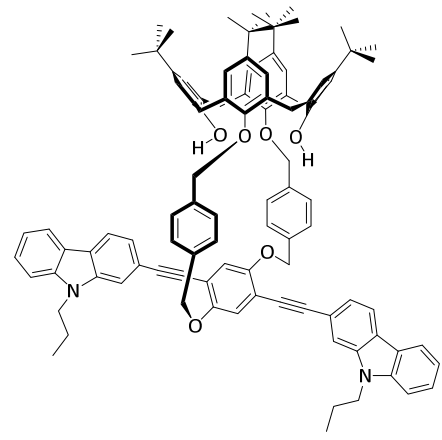

Chart 1. Chemical structure of Calix-OCP-2-CBZ (1) [9].

In this report, the preliminary results on the recognition abilities of $\mathbf{1}$ to $\mathrm{Cu}(\mathrm{I})$ are described. The sensitivity of receptor 1 towards this cation, as copper(I) acetate and copper (I) iodide, was evaluated through fluorimetric titrations using diluted $\mathrm{CH}_{3} \mathrm{CN}: \mathrm{CHCl}_{3}$ (1:1) solutions of fluorescent sensor $\mathbf{1}\left(1 \times 10^{-7} \mathrm{M}\right)$. Due to the limited solubility of CuOAc in the solvent mixture, the salt was previously solubilized in pyridine and then added to the solution of the fluorophore for titration assays. The photostability of $\mathbf{1}$ in the solvent mixture 
was first evaluated under the conditions used in the titration experiments $\left(\lambda_{\text {exc }}=380 \mathrm{~nm}, \mathrm{RA}\right.$ illumination). Fluorescence emission data have shown that no photodegradation occurred up to $1 \mathrm{~h}$ of continuous irradiation. It was also verified that, in the range of concentrations used, no inner-filter effects ascribable to the absorption of incident radiation at the excitation $(380 \mathrm{~nm})$ or emission radiation from the fluorophore (390-550 $\mathrm{nm}$ ) by the metal cations were present, at least to an extent that would require a proper mathematical correction.

As depicted in Figure 1a,b, the emission of calixarene 1 in the presence of $\mathrm{Cu}(\mathrm{I})$, whatever the counter-ion used, is extremely reduced. Indeed, the emission of $\mathbf{1}$ is only quenched by $7.9 \%$ after addition of 300 equiv. of copper acetate salt. When the iodide salt was used, a similar response $(6.6 \%$ attenuation of emission after addition of 300 equiv. of the salt) was found. This outcome discards the possible influence of significant effects of the anions on the binding strengths attained in the complexes.

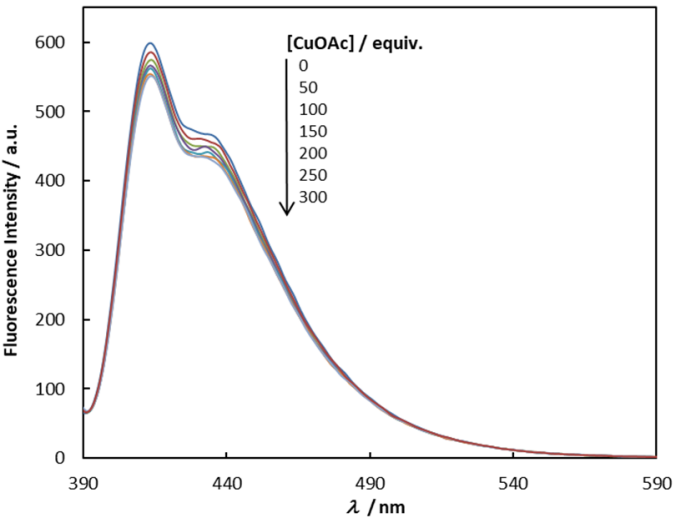

(a)

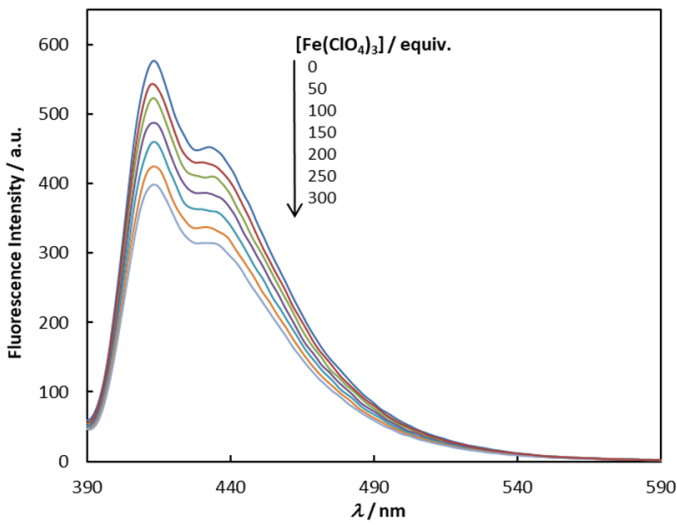

(c)

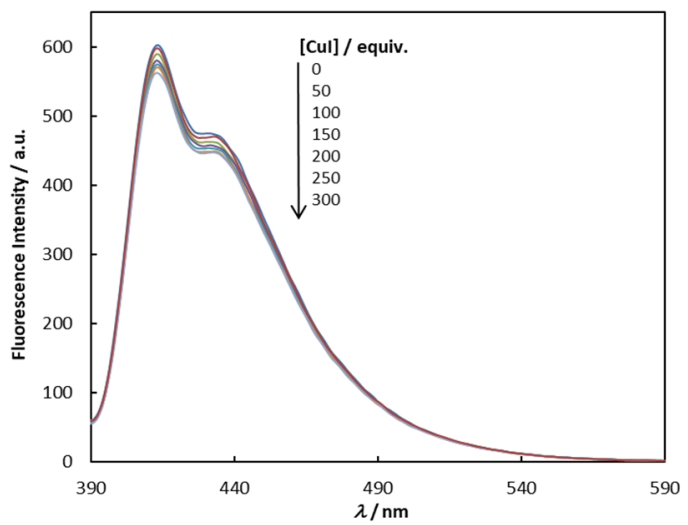

(b)

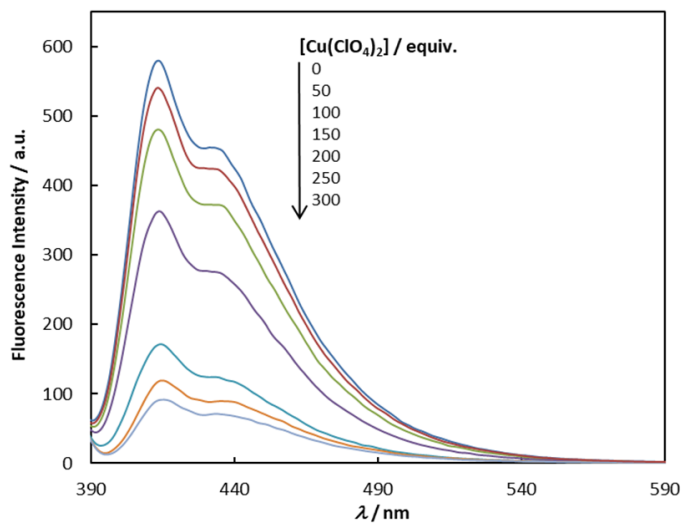

(d)

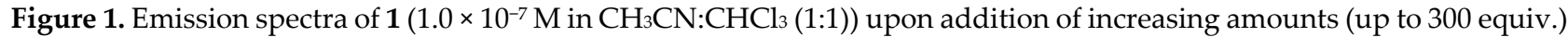
of $\mathrm{CuOAc}(\mathbf{a}), \mathrm{CuI}(\mathbf{b}), \mathrm{Fe}\left(\mathrm{ClO}_{4}\right)_{3}(\mathbf{c})$ and $\mathrm{Cu}\left(\mathrm{ClO}_{4}\right)_{2}(\mathbf{d})\left(\lambda_{\text {exc }}=380 \mathrm{~nm}\right)$.

$\mathrm{Fe}(\mathrm{III})$, the competitor ion chosen for the study, decreases the initial fluorescence intensity of 1 by 31\% upon contact with 300 molar equivalents of this cation. The spectra obtained for this titration are shown in Figure 1c. For comparison purposes, the spectra obtained from the titration experiment with $\mathrm{Cu}(\mathrm{II})$, as its perchlorate salt, are also shown in Figure 1d. In this case, the quenching efficiency reaches $84 \%$ upon addition of 300 equiv. of the salt. 
The binding constants for the three salts were roughly estimated by the Stern-Volmer formalism, assuming a 1:1 stoichiometry for all the intervening complexes. A binding constant (or association constant $\left(K_{\mathrm{a}}\right)$ ) of $2.87 \times 10^{3} \mathrm{M}^{-1}$ was retrieved for $\mathrm{Cu}(\mathrm{I})$, while for Fe(III) and $\mathrm{Cu}(\mathrm{II})$ the values were $K_{\mathrm{a}}=1.25 \times 10^{4} \mathrm{M}^{-1}$ and $K_{\mathrm{a}}=3.85 \times 10^{4} \mathrm{M}^{-1}$, respectively.

Evidence for the formation of ground-state complexes between $\mathbf{1}$ and the metal cations $\mathrm{Cu}(\mathrm{I})$ and $\mathrm{Fe}(\mathrm{III})$ was investigated by UV-Vis titrations. Contrary to what was previously observed for $\mathrm{Cu}$ (II) [8], no evidence for complexation was found, as judged by the absence of any isosbestic points in the spectra (Figure 2a,b).

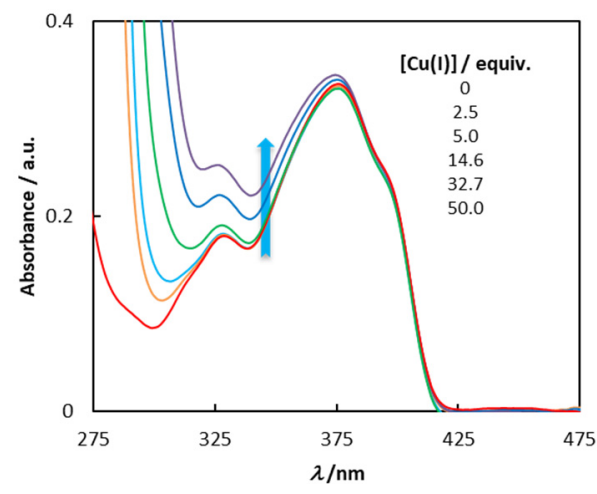

(a)

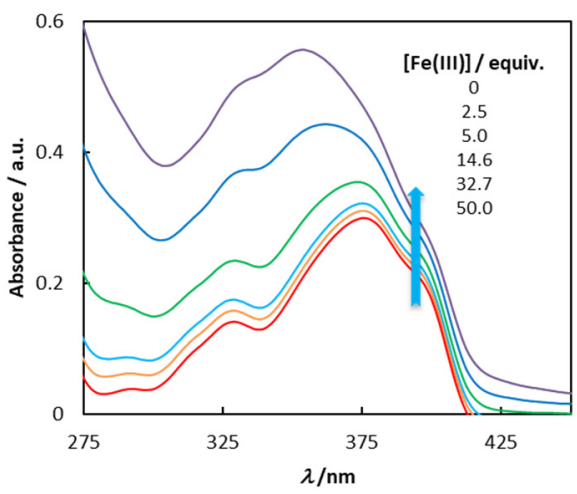

(b)

Figure 2. Absorption spectra of $\mathbf{1}\left(5.0 \times 10^{-6} \mathrm{M}\right.$ in $\left.\mathrm{CH}_{3} \mathrm{CN}: \mathrm{CHCl}_{3}(1: 1)\right)$ upon addition of increasing amounts of $(\mathbf{a}) \mathrm{CuOAc}$ and (b) $\mathrm{Fe}\left(\mathrm{ClO}_{4}\right)_{3}\left(1.24 \times 10^{-5}-2.50 \times 10^{-4} \mathrm{M}\right)$.

Thus, even for Fe(III), which showed a higher affinity to calixarene 1 compared to $\mathrm{Cu}(\mathrm{I})$, the equilibrium concentration of the charge-transfer complex should be relatively low to be observed by UV-Vis spectroscopy.

Solely based on one of our previous observations [8] that the relative success of the binding event will rely, in first place, on the match between the size of the ligand cavity in calixarene 1 and the size of the incoming cation, one would expect a much larger affinity of 1 to $\mathrm{Cu}(\mathrm{I})$ since its ionic radius is very close ( $\left.\mathrm{r}_{\text {ion }}=0.60 \AA\right)$ to that of $\mathrm{Cu}(\mathrm{II})\left(\mathrm{r}_{\text {ion }}=0.57 \AA\right.$ ), both in a square planar tetra-coordinate geometry [10]. Of course, besides that parameter, the scant magnitude of the charge-transfer interactions between $\mathbf{1}$ and $\mathrm{Cu}(\mathrm{I})$ seems to dominate the observed outcome in this case. Further studies are needed to shed light on this issue. The same observation can be made for Fe(III), which has an ionic radius of $0.49 \AA$ (square planar configuration) [10].

\section{Conclusions}

The above-mentioned results indicate that Calix-OCP-2-CBZ (1) is poorly responsive to the presence of copper ions in its reduced oxidation state in an organic solvent matrix. This can be considered an excellent observation since it prospectively allows sensor $\mathbf{1}$ to selectively discriminate between the two most prevalent forms of copper ions in biological processes, namely those occurring in redox-active centers. The binding affinity of $\mathbf{1}$ for $\mathrm{Fe}(\mathrm{III})$ was also explored and a lower sensitivity was obtained when compared to $\mathrm{Cu}$ (II).

Deeper insights on the recognition events underpinning the reported behaviors here described, and those of other relevant transition metal cations, are currently being investigated and will be reported in due course.

Author Contributions: Conceptualization, J.V.P.; methodology, J.V.P.; investigation, A.I.C. and P.D.B.; resources, J.V.P.; data curation, J.V.P.; validation, A.I.C. and P.D.B.; writing-original draft 
preparation, A.I.C. and P.D.B.; writing - review and editing, J.V.P. All authors have read and agreed to the published version of the manuscript.

Funding: This research was funded by Fundação para a Ciência e a Tecnologia/Ministério da Ciência, Tecnologia e Ensino Superior (FCT/MCTES) (UIDB/00616/2020 and UIDP/00616/2020).

Institutional Review Board Statement: Not applicable.

Informed Consent Statement: Not applicable.

Conflicts of Interest: The authors declare no conflicts of interest.

\section{References}

1. Malmström, B.G.; Leckner, J. The chemical biology of copper. J. Curr. Opin. Chem. Biol. 1998, 2, $286-292$.

2. Uriu-Adams, J.Y.; Keen, C.L. Copper, oxidative stress, and human health. Mol. Asp. Med. 2005, 26, $268-298$.

3. Liu, S.; Wang; Y.-M.; Han, J. Fluorescent chemosensors for copper(II) ion: Structure, mechanism and application. J. Photochem. Photobiol. C: Photochem. Rev. 2017, 32, 78-103.

4. $\quad$ Festa, R.A.; Thiele, D.J. Copper: An Essential Metal in Biology. Curr. Biol. 2011, 21, R877-R883.

5. Abbaspour, N.; Hurrell, R.; Kelishadi, R. Review on iron and its importance for human health. J. Res. Med. Sci. 2014, 19, 164174.

6. Gutsche, C.D. Calixarenes-An Introduction. In Monographs in Supramolecular Chemistry; Stoddart, J.F., Ed.; The Royal Society of Chemistry: Cambridge, UK, 2008.

7. Kumar, R.; Sharma, A.; Singh, H.; Suating, P.; Kim, H.S.; Sunwoo, K.; Shim, I.; Gibb, B.C.; Kim, J.S. Revisiting Fluorescent Calixarenes: From Molecular Sensors to Smart Materials. Chem. Rev. 2019, 119, 9657-9721.

8. Costa, A.I.; Barata, P.B.; Fialho, C.F.; Prata, J.V. Highly Sensitive and Selective Fluorescent Probes for Cu(II) Detection Based on Calix[4]arene-Oxacyclophane Architectures. Molecules 2020, 25, 2456.

9. Prata, J.V.; Barata, P.D.; Pescitelli, G. Inherently chiral calix[4]arenes with planar chirality: Two new entries to the family. Pure Appl. Chem. 2014, 86, 1819-1828.

10. Shannon, R.D. Revised effective ionic radii and systematic studies of interatomic distances in halides and chalcogenides. Acta Cryst. A 1976, 32, 751-767. 